\title{
Impact of cardiac rehabilitation on ventricular repolarization indices following coronary artery bypass grafting
}

\author{
Kardiyak rehabilitasyonun koroner arter baypas greftleme sonrası \\ ventriküler repolarizasyon indekslerine etkisi
}

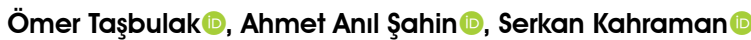

Department of Cardiology, Mehmet Akif Ersoy Thoracic and Cardiovascular Surgery Training and Research Hospital, Istanbul, Turkey

\begin{abstract}
Background: The aim of this study was to evaluate the effect of cardiac rehabilitation on electrocardiographic changes in patients undergoing isolated coronary artery bypass grafting.
\end{abstract}

Methods: Between January 2016 and July 2019, a total of 625 patients (485 males, 140 females; mean age: 59.6 years; range, 50.6 to 68.6 years) who underwent isolated coronary artery bypass grafting and survived were retrospectively analyzed. The patients were divided into two groups according to the participation in the cardiac rehabilitation program as follows: the Rehab(+) group $(n=363)$ and the Rehab(-) group ( $=262)$. Electrocardiographic parameters of both groups were compared.

Results: There was a significant decrease in the electrocardiographic findings of heart rate $(\mathrm{p}<0.001)$, QTc $(\mathrm{p}<0.001)$, Tpe duration $(\mathrm{p}<0.001)$, Tpe/QT ratio $(\mathrm{p}<0.001)$, and Tpe/QTc ratio $(\mathrm{p}<0.001)$ in the $\operatorname{Rehab}(+)$ group before and after surgery. There was a significant decrease in the Rehab(+) group, compared to the Rehab(-) group, in terms of parameters of QT interval $(p=0.001)$, QTc $(p=0.017)$, Tpe duration $(p<0.001)$, Tpe/QT ratio $(\mathrm{p}<0.001)$, and Tpe/QTc ratio $(\mathrm{p}<0.001)$.

Conclusion: Cardiac rehabilitation program after coronary artery bypass grafting decreases ventricular repolarization indices of electrocardiography. Based on these changes, postoperative cardiac rehabilitation program may reduce the risk of ventricular arrhythmia and sudden cardiac death during follow-up.

Keywords: Cardiac rehabilitation, coronary artery bypass grafting, electrocardiography, ventricular repolarization. $\ddot{o} Z$

Amaç: Bu çalışmada, izole koroner arter baypas greftleme yapılan hastalarda kardiyak rehabilitasyonun elektrokardiyografik değişiklikler üzerindeki etkisi değerlendirildi.

Çalışma planı: Ocak 2016-Temmuz 2019 tarihleri arasında, izole koroner arter baypas greftleme yapılan ve sağ kalan toplam 625 hasta (485 erkek, 140 kadın; ort. yaş: 59.6 yıl; dağılım, 50.6-68.6 yıl) retrospektif olarak incelendi. Hastalar kardiyak rehabilitasyon programına katılım durumlarına göre Rehab(+) (n=363) ve Rehab(-) (n=262) olmak üzere iki gruba ayrıldı. Her iki grubun elektrokardiyografik parametreleri karşılaştırıldı.

Bulgular: Ameliyat öncesi ve sonrasında Rehab(+) grubunun elektrokardiyografisinde kalp hızı $(\mathrm{p}<0.001)$, QTc $(\mathrm{p}<0.001)$, Tpe süresi $(\mathrm{p}<0.001)$, Tpe/QT oranı $(\mathrm{p}<0.001)$ ve Tpe/QTc oranında $(\mathrm{p}<0.001)$ anlamlı bir düşüş izlendi. Rehab(-) grubuna kıyasla, Rehab(+) grubunun QT aralığı $(\mathrm{p}=0.001)$, QTc $(p=0.017)$, Tpe süresi $(p<0.001)$, Tpe/QT oran1 $(p<0.001)$ ve Tpe/QTc oranı $(\mathrm{p}<0.001)$ parametrelerinde anlamlı bir düşüş saptand1.

Sonuç: Koroner arter baypas greftleme sonrasında kardiyak rehabilitasyon, elektrokardiyografide ventriküler repolarizasyon indekslerini azaltır. Bu değişikliklere dayanarak, ameliyat sonrası kardiyak rehabilitasyon programı, takip sırasında ventriküler aritmi ve ani kardiyak ölüm riskini azaltabilir.

Anahtar sözcükler: Kardiyak rehabilitasyon, koroner arter baypas greftleme, elektrokardiyografi, ventriküler repolarizasyon.

Received: September 09, 2020 Accepted: December 01, 2020 Published online: April 26, 2021

Correspondence: Ahmet Anıl Şahin, MD. Mehmet Akif Ersoy Göğüs Kalp ve Damar Cerrahisi Eğitim ve Araştırma Hastanesi, Kardiyoloji, 34303 Küçükçekmece, İstanbul, Türkiye. Tel: +90 553 - 2227627 e-mail: aanilsahin@hotmail.com 
Lifestyle changes, particularly regular exercise, are recommended to all patients with cardiovascular disease. ${ }^{[1]}$ Cardiac rehabilitation (CR) is a structured program, which consists of exercises, lifestyle modifications, psychosocial support and education compatible with special conditions of each patient. The $\mathrm{CR}$ is associated with improved clinical outcomes in a broad spectrum of cardiac disease..$^{[2,3]}$ The beneficial effect of $\mathrm{CR}$ has been proven in patients with ischemic heart disease..$^{[4,5]}$

Coronary artery bypass grafting (CABG) is the preferred method for revascularization in patients with left main coronary artery (LMCA) or three-vessel disease. ${ }^{[6]}$ Dysrhythmias are common after CABG and may be associated with cardiovascular death and major adverse cardiovascular events. ${ }^{[7]}$ Electrocardiography (ECG) is the preferred method for detecting electrical instability of the myocardium. T wave, QRS wave, and QT interval on ECG may provide useful information about ventricular repolarization and ventricular electrical activity ${ }^{[8,9]}$

In the present study, we aimed to evaluate the effect of $\mathrm{CR}$ on ECG changes in patients who underwent isolated CABG surgery.

\section{PATIENTS AND METHODS}

This single-center, retrospective study was conducted at Mehmet Akif Ersoy Thoracic and Cardiovascular Surgery Training and Research Hospital, Department of Cardiology between January 2016 and July 2019. Patients were selected among cases who underwent isolated CABG surgery. A total of 699 consecutive patients who underwent isolated CABG surgery and survived in their postoperative follow-up were screened. Exclusion criteria were as follows: having atrial fibrillation or atrial flutter on ECG during preor postoperative follow-up $(n=19)$, unreadable ECG $(n=20)$, history of pacemaker implantation $(n=1)$, postoperative junctional rhythm $(n=1)$, drug use altering QT interval including type I and III antiarrhythmic drugs $(n=14)$, electrolyte imbalance of hemodialysis during follow-up $(\mathrm{n}=14)$, myocardial infarction during follow-up $(\mathrm{n}=4)$, and pre-excitation syndrome $(\mathrm{n}=1)$. After applying the exclusion criteria, 625 patients (485 males, 140 females; mean age: 59.6 years; range, 50.6 to 68.6 years) were included in the study. Demographic characteristics, concomitant diseases, and cardiovascular risk factors of the patients were recorded. A written informed consent was obtained from each patient. The study protocol was approved by the Mehmet Akif Ersoy Thoracic and Cardiovascular Surgery Training and Research Hospital Ethics Committee (date/no: 18.08.20202020/60). The study was conducted in accordance with the principles of the Declaration of Helsinki.

The patients were divided into two groups according to the participation in the CR program as follows: the $\operatorname{Rehab}(+)$ group $(n=363)$ consisting of patients who participated in CR program after isolated CABG surgery and the Rehab(-) group $(n=262)$ consisting of patients who were unwilling to or could not participate in CR program after isolated CABG surgery. Electrocardiographic data of the both groups before operation, and at the six months after the operation (in the end of CR program for Rehab $(+)$ and in the routine follow-up for Rehab(-) group) were evaluated from the hospital computer system.

\section{CR protocol}

In our hospital, all the patients are routinely invited to $\mathrm{CR}$ program after complete recovery following the surgery ( $\sim 3$ months after surgery). Exercise tolerance test was performed in the CR unit for patients who accepted to participate in the $\mathrm{CR}$ program. At the beginning of the test, cycling with 30 Watts of pedal load and 15 Watts increment was applied every 2 min with constant pedaling speed of 55 to 65 per min. Individual exercise programs were revised by weekly assessments according to improvements in physical fitness. Each training session included reduced load warming and cooling periods for $5 \mathrm{~min}$ in the beginning and the end of the training. Each exercise session was finished with stretching and strengthening exercises. Cardiac rehabilitation program was performed three days per week for 10 weeks in the hospital.

\section{Electrocardiography}

A 12-lead surface ECG (Nihon Kohden Corporation, Cardiofax M Model ECG-1250, Tokyo, Japan) was performed in the supine position, with a $25 \mathrm{~mm} / \mathrm{sec}$ paper speed and a voltage of $10 \mathrm{~mm} / \mathrm{sec}$ for each patient. All ECG data were scanned and transferred to the hospital's main computer system. Analyses were performed by two cardiologists who were blinded to the patients' data via using the software of Adobe Photoshop (Adobe Systems Inc., San Jose, CA, USA) with $\times 400 \%$ magnification. The average of independently measured parameters was used for analysis. Distance between the waves of $\mathrm{Q}$ and $\mathrm{T}$ were defined as QT interval, while distance between the peak and the end of the $\mathrm{T}$ wave was defined as Tpe interval. Three consecutive QT intervals were measured from the first deflection of the QRS complex to the point of return of the $\mathrm{T}$ wave to isoelectric line. 
If $\mathrm{U}$ wave was present, the end of the $\mathrm{T}$ wave was taken as the nadir between $\mathrm{T}$ and $\mathrm{U}$ waves. Additionally, corrected QT (QTc) was calculated by using Bazett's formula $\left(\mathrm{QTc}=\mathrm{QT} / \sqrt{\mathrm{RR}}\right.$ interval) ${ }^{[10]}$ The $\mathrm{QT}$ interval was measured in as many of the 12 leads as possible, whereas Tpe interval was assessed in the precordial leads. The Tpe interval was measured from the peak of the $\mathrm{T}$ wave to the end of the $\mathrm{T}$ wave. The end of the $\mathrm{T}$ wave was defined as the intersection of the tangent to the downslope of the $\mathrm{T}$ wave and isoelectric line. The Tpe and QT ratio (Tpe/QT) and Tpe and QTc ratio (Tpe/QTc) were calculated from these measurements. The inter- and intra-observer coefficients of variation were $2.0 \%$ and $2.4 \%$, respectively.

\section{Statistical analysis}

Statistical analysis was performed using the IBM SPSS version 24.0 (IBM Corp., Armonk, NY, USA). Whether the variables showed normal distribution, visual (histograms, probability curves) and analytical methods (Kolmogorov-Smirnov and Shapiro-Wilk tests) were evaluated. Numerical variables showing normal distribution were expressed in mean \pm standard deviation (SD), while numerical variables not showing normal distribution were expressed in median (interquartile range [IQR]) and categorical variables in number and percentage. The chi-square or Fisher exact test were used to compare categorical variables between groups. Since the distributions of the differences in the dependent variables (ECG parameters) were non-normally distributed, the Wilcoxon signed-rank test was used to assess the changes in ECG parameters. The distribution of differences between the ECG parameters were assessed using histogram pilots to ensure they were symmetrical in shape, since the Wilcoxon signed-rank test requires dependent variables with symmetrical distribution. The McMemar's test was used to compare the differences in categorical variables. A $p$ value of $<0.05$ was considered statistically significant.

\section{RESULTS}

Table 1 shows demographic data of the both groups. There was no significant difference between the groups in terms of preoperative ECG findings.

The patients using any medication those altering QT intervals as one of the exclusion criteria were

Table 1. Demographic, clinical, laboratory, and electrocardiographic findings of patients before isolated coronary artery bypass grafting

\begin{tabular}{|c|c|c|c|c|c|c|c|c|c|c|c|}
\hline & \multicolumn{5}{|c|}{$\begin{array}{l}\text { Patients who did not undergo } \\
\text { cardiac rehabilitation }(n=262)\end{array}$} & \multicolumn{5}{|c|}{$\begin{array}{c}\text { Patients who underwent } \\
\text { cardiac rehabilitation }(n=363)\end{array}$} & \multirow[b]{2}{*}{$p$} \\
\hline & $\mathrm{n}$ & $\%$ & Mean \pm SD & Median & Min-Max & $\mathrm{n}$ & $\%$ & Mean \pm SD & Median & Min-Max & \\
\hline Age (year) & & & $59.2 \pm 9.4$ & & & & & $59.9 \pm 8.7$ & & & 0.385 \\
\hline \multicolumn{12}{|l|}{ Sex } \\
\hline Male & 202 & 77.1 & & & & 283 & 78 & & & & 0.799 \\
\hline COPD & 40 & 15.3 & & & & 47 & 12.9 & & & & 0.408 \\
\hline PAD & 14 & 5.3 & & & & 42 & 11.6 & & & & 0.007 \\
\hline Smoking & 97 & 37 & & & & 115 & 31.7 & & & & 0.164 \\
\hline Diabetes mellitus & 147 & 56.1 & & & & 197 & 54.3 & & & & 0.649 \\
\hline Hypertension & 193 & 73.7 & & & & 295 & 81.3 & & & & 0.023 \\
\hline HFrEF & 20 & 7.6 & & & & 28 & 7.7 & & & & 0.970 \\
\hline LVEF & & & & 57 & $50-60$ & & & & 60 & $50-60$ & 0.065 \\
\hline Creatinine (mg/dL) & & & & 0.87 & $0.74-1.03$ & & 6.6 & & 0.90 & $0.78-1.06$ & 0.330 \\
\hline Heart rate $(/ \mathrm{min})$ & & & & 81 & 71-89 & & & & 78 & 71-87 & 0.338 \\
\hline QT interval (ms) & & & & 380 & $354-400$ & & & & 380 & $358-404$ & 0.369 \\
\hline QTc & & & & 432 & $416-451$ & & & & 430 & $415-451$ & 0.083 \\
\hline QRS duration (ms) & & & & 82 & $76-90$ & & & & 82 & $76-92$ & 0.699 \\
\hline Tpe duration (ms) & & & & 82 & $74-88$ & & & & 83 & $75-91$ & 0.101 \\
\hline Tpe/QT ratio & & & & 0.21 & $0.20-0.24$ & & & & 0.22 & $0.20-0.24$ & 0.475 \\
\hline Tpe/QTc ratio & & & & 0.19 & $0.17-0.20$ & & & & 0.19 & $0.17-0.21$ & 0.140 \\
\hline
\end{tabular}

SD: Standard deviation; Min: Minimum; Max: Maximum; COPD: Chronic obstructive pulmonary disease; PAD: Peripheral artery disease, HFrEF: heart failure with reduced ejection fraction, LVEF: Left ventricular ejection fraction. 
Table 2. Electrocardiographic findings of patients in Rehab(+) group before surgery and after cardiac rehabilitation following isolated CABG

\begin{tabular}{|c|c|c|c|c|c|}
\hline & \multicolumn{2}{|c|}{$\begin{array}{c}\text { Before CABG and } \\
\text { cardiac rehabilitation }\end{array}$} & \multicolumn{2}{|c|}{$\begin{array}{c}\text { After cardiac rehabilitation } \\
\text { following } \mathrm{CABG}\end{array}$} & \multirow[t]{2}{*}{$p$} \\
\hline & Median & Min-Max & Median & Min-Max & \\
\hline Heart rate $(/ \min )$ & 78 & $71-87$ & 71 & $65-79$ & $<0.001$ \\
\hline QT interval (ms) & 380 & $358-404$ & 379 & $361-403$ & 0.428 \\
\hline QTc & 430 & $415-451$ & 425 & $408-443$ & $<0.001$ \\
\hline QRS duration (ms) & 82 & $76-92$ & 82 & 78-92 & 0.004 \\
\hline Tpe duration (ms) & 83 & $75-91$ & 70 & $62-76$ & $<0.001$ \\
\hline Tpe/QT ratio & 0.22 & $0.20-0.24$ & 0.18 & $0.16-0.20$ & $<0.001$ \\
\hline Tpe/QTc ratio & 0.19 & $0.17-0.21$ & 0.16 & $0.14-0.18$ & $<0.001$ \\
\hline
\end{tabular}

CABG: Coronary artery bypass grafting.

not included in the study. However, all patients were taking optimal medical therapy for atherosclerotic cardiovascular disease, including optimal dosage of beta-blockers (except for sotalol as one of the type III antiarrhythmic drugs). The number of betablocker usage was 245/262 (93.5\%) for Rehab(-) group and 351/363 (96.7\%) for Rehab(+) group, preoperatively. In the sixth month follow-up, the number of beta-blocker usage for Rehab(-) group was 250/262 (95.4\%) and for Rehab(+) group was $343 / 363(94.5 \%)$.

Table 2 shows comparison of ECG findings for Rehab(+) group before and after CR program. There was a significant difference in the ECG findings of all parameters, except for median QT interval. Heart rate (before CR: 78 (71-87) vs. after CR: 71 (65-79); p<0.001), QTc (before CR: 430
(415-451) vs. after CR: 425 (408-443); p<0.001), Tpe duration (before CR: 83 (75-91) vs. after CR: 70 (62-76); $\mathrm{p}<0.001$ ), Tpe/QT ratio (before CR: 0.22 (0.20-0.24) vs. after CR: $0.18(0.16-0.20)$; $<<0.001)$, and Tpe/QTc ratio (before CR: $0.19(0.17-0.21)$ vs. after CR: $0.16(0.14-0.18) ; \mathrm{p}<0.001)$ were found to decrease significantly after CR program.

The ECG findings of the Rehab(-) group are given in Table 3 . The table included the comparison of the preoperative and six-month postoperative ECG findings of the groups. The median heart rate (preoperative: 81 (71-89) vs. postoperative: 72 (65-83); $\mathrm{p}<0.001)$, QT interval (preoperative: 380 (353-400) vs. postoperative: 389 (368-416); $\mathrm{p}<0.001$ ), Tpe/QT ratio (preoperative: 0.21 (0.20-0.24) vs. postoperative: $0.20 \quad(0.18-0.22)$; $\mathrm{p}<0.001)$ significantly decreased after the operation.

Table 3. Pre- and postoperative (at Month 6) ECG findings of patients who did not undergo cardiac rehabilitation after isolated CABG $(n=262)$

\begin{tabular}{|c|c|c|c|c|c|}
\hline & \multicolumn{2}{|c|}{$\begin{array}{l}\text { Before CABG and } \\
\text { cardiac rehabilitation }\end{array}$} & \multicolumn{2}{|c|}{$\begin{array}{l}\text { After cardiac rehabilitation } \\
\text { following CABG }\end{array}$} & \multirow[t]{2}{*}{$p$} \\
\hline & Median & Min-Max & Median & Min-Max & \\
\hline Heart rate $(/ \mathrm{min})$ & 81 & $71-89$ & 72 & $65-83$ & $<0.001$ \\
\hline QT interval (ms) & 380 & $353-400$ & 389 & $368-416$ & $<0.001$ \\
\hline QTc & 432 & $416-451$ & 430 & $412-450$ & 0.145 \\
\hline QRS duration (ms) & 82 & $76-90$ & 84 & $78-90$ & $<0.001$ \\
\hline Tpe duration (ms) & 82 & $74-88$ & 80 & $74-88$ & 0.898 \\
\hline Tpe/QT ratio & 0.21 & $0.20-0.24$ & 0.20 & $0.18-0.22$ & $<0.001$ \\
\hline Tpe/QTc ratio & 0.18 & $0.17-0.20$ & 0.18 & $0.17-0.20$ & 0.535 \\
\hline
\end{tabular}

ECG: Electrocardiography; CABG: Coronary artery bypass grafting. 
Table 4. Comparison of ECG findings of patients receiving or not receiving cardiac rehabilitation six months after isolated CABG

\begin{tabular}{|c|c|c|c|c|c|}
\hline & \multicolumn{2}{|c|}{ Rehab(-) group (n=262) } & \multicolumn{2}{|c|}{ Rehab(+) group (n=363) } & \multirow[t]{2}{*}{$p$} \\
\hline & Median & Min-Max & Median & Min-Max & \\
\hline Heart rate $(/ \mathrm{min})$ & 72 & $65-83$ & 71 & $65-79$ & 0.245 \\
\hline QT interval (ms) & 389 & $368-416$ & 379 & $361-403$ & 0.001 \\
\hline QTc & 430 & $412-450$ & 425 & $408-443$ & 0.017 \\
\hline QRS duration (ms) & 84 & $78-90$ & 82 & $78-92$ & 0.867 \\
\hline Tpe duration (ms) & 80 & $74-88$ & 70 & $62-76$ & $<0.001$ \\
\hline Tpe/QT ratio & 0.20 & $0.18-0.22$ & 0.18 & $0.16-0.20$ & $<0.001$ \\
\hline Tpe/QTc ratio & 0.18 & $0.17-0.20$ & 0.16 & $0.14-0.18$ & $<0.001$ \\
\hline
\end{tabular}

ECG: Electrocardiography; CABG: Coronary artery bypass grafting.

There was no significant difference in the QTc, Tpe duration, and Tpe/QTc ratio. Additionally, the median QRS duration (preoperative: 82 (76-90) vs. postoperative: $84(78-90) ; \mathrm{p}<0.001)$ was found to increase significantly after surgery.

The comparison of ECG findings between the Rehab(+) and Rehab(-) groups is presented in Table 4. There was a significant decrease in the parameters of median QT interval (Rehab(-) group: 389 (368-416) vs. Rehab(+) group: 379 (361-403); $\mathrm{p}=0.001)$, QTc (Rehab(-) group: 430 (412-450) vs. Rehab(+) group: 425 (408-443); p=0.017), Tpe duration (Rehab(-) group: 80 (74-88) vs. Rehab(+) group: 70 (62-76); p<0.001), Tpe/QT ratio (Rehab(-) group: $0.20(0.18-0.22)$ vs. Rehab(+) group: 0.18 (0.16-0.20); $\mathrm{p}<0.001)$, and Tpe/QTc ratio (Rehab(-) group: 0.18 (0.17-0.20) vs. Rehab(+) group: 0.16 $(0.14-0.18) ; \mathrm{p}<0.001]$. There was no significant difference in the heart rate and QRS duration between the groups.

\section{DISCUSSION}

In the present study, we evaluated the effect of CR on ECG changes in patients who underwent isolated CABG surgery. The main finding of our study was that the CR program significantly changed ECG findings of the patients, compared to the patients who did not undergo CR program. These changes were mainly parameters providing information about ventricular repolarization. The parameters including ventricular repolarization such as QT interval, QTc, Tpe duration, Tpe/QT ratio, Tpe/QTc ratio decreased in the Rehab(+) group, compared to the Rehab(-) group, which may be associated with the reduced risk of ventricular arrhythmias.
It is well known that QT interval and QTc are parameters used to predict ventricular arrhythmias. ${ }^{[11]}$ In addition, Tpe duration, Tpe/QT ratio, and Tpe/QTc ratio have been shown to be useful parameters in the evaluation of ventricular repolarization and ventricular arrhythmogenesis together with sudden cardiac death. ${ }^{[9,12]}$ Prolongation of parameters such as QT interval, QTc, Tpe duration, Tpe/QT ratio, and Tpe/QTc ratio reflect abnormal ventricular repolarization and are the markers of arrhythmias.

The QT interval and QTc may be prolonged due to ischemia ${ }^{[13]}$ After revascularization, the prolongation in the acute setting may be reversed. ${ }^{[14,15]}$ However, the effect of revascularization in chronic conditions is still controversial. ${ }^{[6]}$ Some studies found increased QT interval and QTc after CABG, ${ }^{[17]}$ while some others found vice versa. ${ }^{[18]}$ In our study, there was no significant difference between the groups before CABG surgery. During follow-up, the patients in the Rehab(-) group had a significant decrease in the parameters of heart rate and Tpe/QT ratio and had a significant increase in the QT interval and QRS duration. However, there was no difference in the parameters of QTc, Tpe duration and Tpe/QTc ratio. These findings could not be explained accurately due to different findings in the statistical analyses. However, in the Rehab(+) group, the patients had a significant decrease in all parameters, except for QT interval after $\mathrm{CR}$ program following CABG surgery. The QT interval was also found to decrease, although the difference was not statistically significant. These findings indicate that $\mathrm{CR}$ program following $\mathrm{CABG}$ surgery significantly reduces the indices related to ventricular repolarization, which are associated with the decreased risk of malignant ventricular arrhythmias. In our study, we compared the ECG findings of patients 
in the Rehab(+) and Rehab(-) groups to further enhance the positive effect of CR program. All indices related of ventricular repolarization significantly decreased in the Rehab(+) group, compared to the Rehab(-) group.

In the literature, there are studies evaluating the effect of CR program on ECG in different study groups. Kalapura et al. ${ }^{[19]}$ found that CR program decreased QT interval in patients who had acute myocardial infarction. In another study, Ali et al. ${ }^{[20]}$ investigated the effect of CR program in patients with heart failure and found that $\mathrm{CR}$ decreased QT interval in these patients. The known mechanism underlying ECG changes after $\mathrm{CR}$ program is the increased autonomic cardiac control after CR program. Gambassi et al. ${ }^{[21]}$ studied the patients who underwent CR program after CABG surgery and found that the autonomic control of the cardiac conduction was improved after CR.

A similar study in the literature to our study was the Vasheghani-Farahani et al.'s ${ }^{[22]}$ study. The authors investigated ventricular repolarization indices after CR program in patients who had CABG surgery. They compared 60 patients who underwent CR program following $\mathrm{CABG}$ with 62 patients who did not undergo $\mathrm{CR}$ program postoperatively. They found that $\mathrm{CR}$ program improved and decreased QT interval and QTc. Of note, our sample size was about five times larger than the aforementioned study, and we also evaluated changes in $\mathrm{T}$ wave, which were closely related to ventricular repolarization.

There is a limited number of studies in the literature evaluating the effect of CR program in parameters of Tpe duration, Tpe/QT ratio, and Tpe/QTc ratio. Nishi et al. ${ }^{[23]}$ showed that Tpe and QTc decreased in 10 patients with cardiac diseases after CR program. In another study, Cerşit and Cerşit ${ }^{[23]}$ showed that CR program decreased Tpe duration, Tpe/QT, and Tpe/QTc ratio in patients with rheumatoid arthritis. To the best of our knowledge, in the literature, there is no study evaluating the effect of CR program on $\mathrm{T}$ wave in patients undergoing CABG surgery. Our study is the first to show that CR program significantly decreased Tpe duration, Tpe/QT, and Tpe/QTc ratio after CABG surgery.

Nonetheless, there are certain limitations to this study. First, the parameters were identified retrospectively and, therefore, this study has inherent limitations due to the retrospective design. Second, we did not have 24-h rhythm monitoring of the patients during follow-up to detect ventricular arrhythmia. Therefore, we could not evaluate the direct link between ventricular arrhythmia and ECG findings.
Third, we did not follow the patients in the long-term to evaluate long-term outcomes of ECG findings.

In conclusion, cardiac rehabilitation program after coronary artery bypass grafting should be recommended to all individuals after recovery period. The postoperative cardiac rehabilitation can improve and decrease ventricular repolarization indices of ECG, including parameters related to QT interval and $\mathrm{T}$ wave. Based on these changes, cardiac rehabilitation program after coronary artery bypass grafting may reduce the risk of ventricular arrhythmia and sudden cardiac death during follow-up of these patients.

\section{Declaration of conflicting interests}

The authors declared no conflicts of interest with respect to the authorship and/or publication of this article.

\section{Funding}

The authors received no financial support for the research and/or authorship of this article.

\section{REFERENCES}

1. Williams B, Mancia G, Spiering W, Agabiti Rosei E, Azizi M, Burnier M, et al. 2018 ESC/ESH Guidelines for the management of arterial hypertension. Eur Heart $\mathrm{J}$ 2018;39:3021-104.

2. Beauchamp A, Worcester M, Ng A, Murphy B, Tatoulis $\mathrm{J}$, Grigg L, et al. Attendance at cardiac rehabilitation is associated with lower all-cause mortality after 14 years of follow-up. Heart 2013;99:620-5.

3. McMahon SR, Ades PA, Thompson PD. The role of cardiac rehabilitation in patients with heart disease. Trends Cardiovasc Med 2017;27:420-5.

4. Malfatto G, Facchini M, Bragato R, Branzi G, Sala L, Leonetti G. Short and long term effects of exercise training on the tonic autonomic modulation of heart rate variability after myocardial infarction. Eur Heart $\mathbf{J}$ 1996;17:532-8.

5. O'Connor GT, Buring JE, Yusuf S, Goldhaber SZ, Olmstead EM, Paffenbarger RS Jr, et al. An overview of randomized trials of rehabilitation with exercise after myocardial infarction. Circulation 1989;80:234-44.

6. Serruys PW, Morice MC, Kappetein AP, Colombo A, Holmes DR, Mack MJ, et al. Percutaneous coronary intervention versus coronary-artery bypass grafting for severe coronary artery disease. N Engl J Med 2009;360:961-72.

7. Rubin DA, Nieminski KE, Monteferrante JC, Magee T, Reed GE, Herman MV. Ventricular arrhythmias after coronary artery bypass graft surgery: Incidence, risk factors and longterm prognosis. J Am Coll Cardiol 1985;6:307-10.

8. Kors JA, Ritsema van Eck HJ, van Herpen G. The meaning of the Tp-Te interval and its diagnostic value. J Electrocardiol 2008;41:575-80.

9. Smetana P, Schmidt A, Zabel M, Hnatkova K, Franz M, Huber K, et al. Assessment of repolarization heterogeneity for prediction of mortality in cardiovascular disease: Peak to 
the end of the $\mathrm{T}$ wave interval and nondipolar repolarization components. J Electrocardiol 2011;44:301-8.

10. Goldenberg I, Moss AJ, Zareba W. QT interval: How to measure it and what is "normal". J Cardiovasc Electrophysiol 2006; 17:333-6.

11. Higham PD, Furniss SS, Campbell RW. QT dispersion and components of the QT interval in ischaemia and infarction. Br Heart J 1995;73:32-6.

12. Kors JA, Ritsema van Eck HJ, van Herpen G. The meaning of the Tp-Te interval and its diagnostic value. J Electrocardiol 2008;41:575-80.

13. Aydinlar A, Sentürk T, Ozdemïr B, Kaderli AA, Aydin O. Effect of percutaneous transluminal coronary angioplasty on QT dispersion and heart rate variability parameters. Cardiovasc J Afr 2009;20:240-4.

14. Aytemir K, Yap YG, Ozmen F. Effect of acute ischemia on QT dispersion. Am Heart J 1999;138:385-6.

15. Jiménez-Candil J, González IC, González Matas JM, Albarrán C, Pabón P, Moríñigo JL, et al. Short- and longterm prognostic value of the corrected QT interval in the non-ST-elevation acute coronary syndrome. J Electrocardiol 2007;40:180-7.

16. Papadopoulos CE, Zaglavara T, Karvounis HI, Haaverstad $\mathrm{R}$, Parharidis GE, Louridas GE, et al. QT dispersion is determined by the relative extent of normal, hibernating, and scarred myocardium in patients with chronic ischemic cardiomyopathy. A dobutamine stress echocardiography study before and after surgical revascularization. J Electrocardiol 2006;39:103-9.

17. Cagli K, Ozbakir C, Ergun K, Bakuy V, Circi R, Circi P. Electrocardiographic changes after coronary artery surgery. Asian Cardiovasc Thorac Ann 2006;14:294-9.
18. Gulcan O, Sezgin AT, Demircan S, Atalay H, Turkoz R. Effect of coronary artery bypass grafting and aneurysmectomy on QT dispersion in moderate or severe left ventricular dysfunction. Am Heart J 2005;149:917-20.

19. Kalapura T, Lavie CJ, Jaffrani W, Chilakamarri V, Milani RV. Effects of cardiac rehabilitation and exercise training on indexes of dispersion of ventricular repolarization in patients after acute myocardial infarction. Am J Cardiol 2003;92:292-4.

20. Ali A, Mehra MR, Malik FS, Lavie CJ, Bass D, Milani RV. Effects of aerobic exercise training on indices of ventricular repolarization in patients with chronic heart failure. Chest 1999;116:83-7.

21. Gambassi BB, Almeida FJF, Almeida AEAF, Ribeiro DAF, Gomes RSA, Chaves LFC, et al. Acute response to aerobic exercise on autonomic cardiac control of patients in phase III of a cardiovascular rehabilitation program following coronary artery bypass grafting. Braz J Cardiovasc Surg 2019;34:305-10.

22. Vasheghani-Farahani A, Asef-Kabiri L, Masoudkabir F, Davoodi G, Nejatian M, Saadat S, et al. Effect of exercisebased cardiac rehabilitation following coronary artery bypass surgery on ventricular repolarization indices. J Cardiopulm Rehabil Prev 2011;31:239-44.

23. Nishi I, Sugiyama A, Takahara A, Kuroki K, Igawa M, Enomoto T, et al. Utility of short-term variability of repolarization as a marker for monitoring a safe exercise training program in patients with cardiac diseases. Int Heart J 2011;52:304-7.

24. Cerşit S, Cerşit HP. Impact of cardiac rehabilitation on ventricular repolarization indexes in patients with rheumatid arthritis. J Electrocardiol 2018;51:787-91. 